\title{
Synthesis and Characterization of Fatty Acid
}

\section{Conjugates of Niacin and Salicylic Acid}

Chi B. Vu, * Jean E. Bemis, Ericka Benson, Pradeep Bista, David Carney, Richard Fahrner, Reema Harish, Diana Lee, Feng Liu, Pallavi Lonkar, Dominic Picarella, Adam Shoelson, Jesse Smith, Amal Ting, Rick Vega, Allison Wensley, Marie Yeager, Michael Zimmer, Jill C. Milne, Michael R. Jirousek and Andrew Nichols.

Catabasis Pharmaceuticals, One Kendall Square, Suite B14202, Cambridge, MA 02139.

\section{Supporting Information}

Tissue distribution study for compound 5: This study was designed to determine the concentration of compound $\mathbf{5}$ and its metabolites in select tissues when dosed once daily (QD) in Sprague-Dawley (SD) rats $(\mathrm{n}=4)$ at $300 \mathrm{mg} / \mathrm{kg}$ over 3, 7, 14 days. At the end of these dosing periods, plasma, epididymal fat, liver, kidney, spleen, brain, and skeletal muscle tissue were collected at 4 hours post final dose and analyzed for $\mathbf{5}$, nicotinic acid and nicotinuric acid concentrations. This design allowed for the determination of the time-to-steady-state concentrations in tissue as well as for the extent of tissue accumulation. A separate wash-out period in which the rats were dosed for 14 days followed immediately by a 7-day non-dosing period was built into the study to measure the extent of clearance of compound $\mathbf{5}$ from the tissues.

When dosed by oral gavage once daily at $300 \mathrm{mg} / \mathrm{kg}$, compound 5 reached steady state concentration levels in plasma, kidney, epididymal fat and liver tissues by day 7 of dose administration (14 total doses) (Figure 1S). There was no significant level of compound 5 measured in the brain or spleen tissue at any of the time points tested across the 28 day period. Within the various tissues, the highest concentration of compound $\mathbf{5}$ was found in the kidney tissue and the lowest concentration was measured in the liver. After the 7-day washout period, compound $\mathbf{5}$ was not detectable in any of the tissues sampled: plasma, epididymal fat, kidney, liver, spleen, brain or skeletal muscle tissues. Thus compound $\mathbf{5}$ is completely cleared from these tissues within 7 days. 
Figure 1S. Tissue levels corresponding to the parent compound 5 upon oral dosing in Sprague Dawley rats.

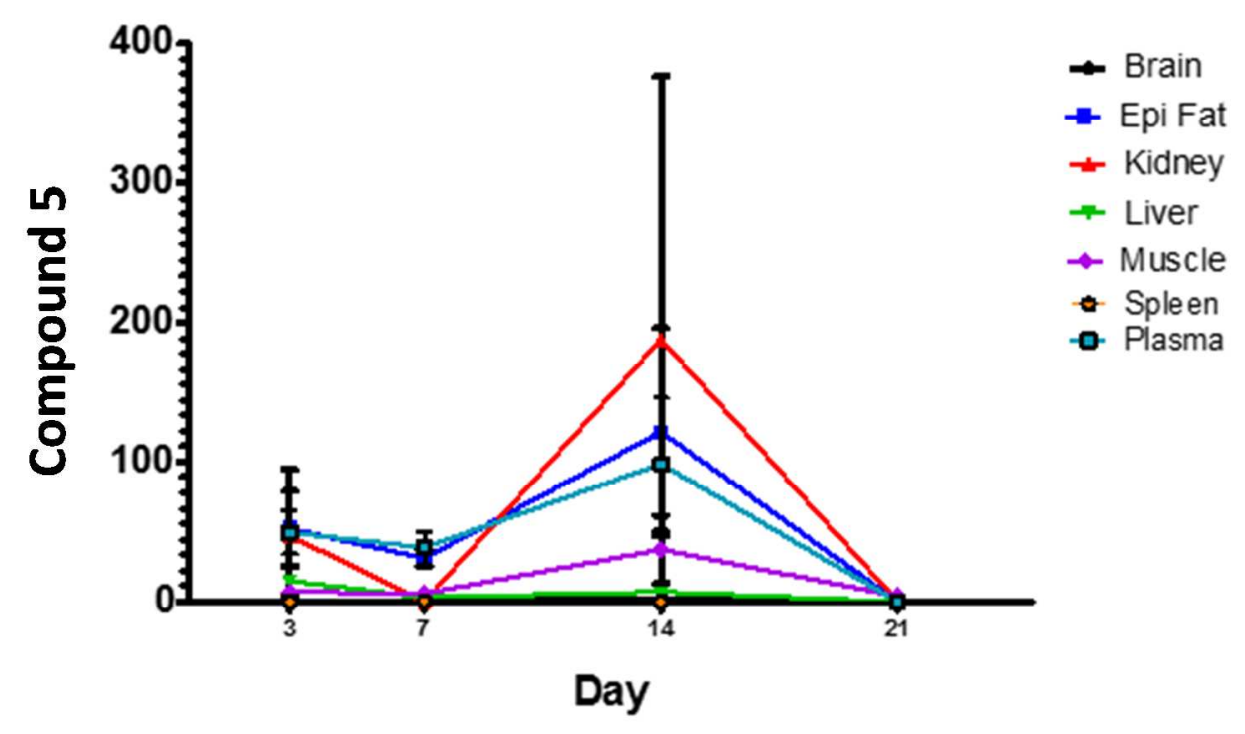

Nicotinic acid was not detected in the plasma or tissues at the indicated time periods.

Nicotinuric acid is a phase 2 metabolite formed through the conjugation of nicotinic acid and glycine in the liver which is subsequently secreted into the plasma for elimination through the kidney. After dosing with compound 5 at $300 \mathrm{mg} / \mathrm{kg}$ orally once a day, the levels of the metabolite nicotinuric acid achieved a relatively constant state after 3 days of dosing across the tissues sampled. The highest concentrations were observed in kidney, fat, and plasma, with lower nicotinuric acid measured in liver, muscle, spleen, and brain tissues. Also in line with the parent compound $\mathbf{5}$, the nicotinuric acid was completely cleared from all tissues after the 7-day washout period (Figure $2 \mathrm{~S}$ ).

Figure 2S. Tissue levels corresponding to nicotinuric acid upon oral dosing with $\mathbf{5}$ in Sprague Dawley rats.

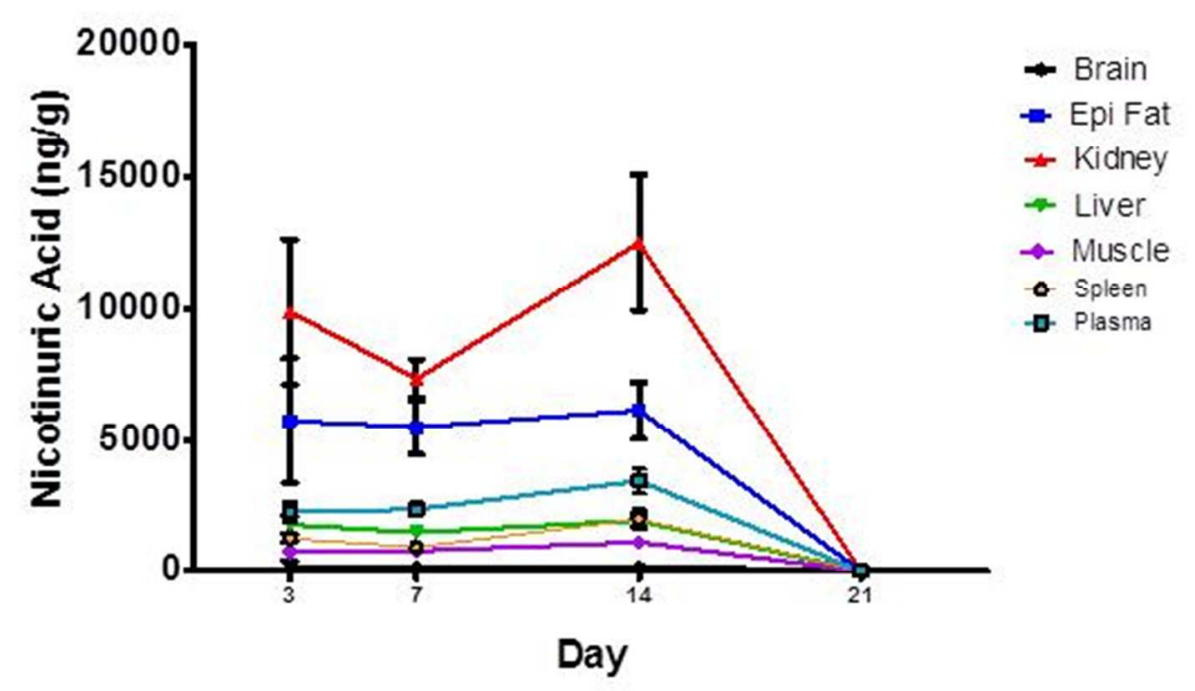


Comparison between compounds 5 and 8 in dual cannulated rats: The goal of designing compounds $\mathbf{7}$ and $\mathbf{8}$ was to minimize hydrolysis in intestinal epithelial cells following oral dosing and thereby maximize the delivery the intact parent compound to the liver. To test this, the in vivo hepatic and jugular portal circulation exposure of compounds $\mathbf{7}$ and $\mathbf{8}$ was assessed in a dual cannulated study in rats and compared to the exposure of compound $\mathbf{5}$ in a parallel study. Blood samples in each study were collected from portal and jugular vein cannulas at 10, 20, 40, 60, 90, 120, and 240 minutes following oral administration of $30 \mathrm{mg} / \mathrm{kg}$ compounds $\mathbf{7 , 8}$ or compound 5 to Sprague-Dawley rats. In rat, compound $\mathbf{5}$ hydrolyzes very rapidly in intestinal epithelial cells and the fraction of the dose administered that appears in the portal circulation is $6 \%$ of the administered dose. Compounds $\mathbf{7}$ and $\mathbf{8}$ hydrolyze at a significantly slower rate and allows more intact parent compound to enter the portal circulation for uptake by the liver (Figure 3S). Figures $4 \mathrm{~S}$ and $5 \mathrm{~S}$ show the corresponding exposure for the niacin linker metabolite and nicotinuric acid.

Figure 3S. Parent exposure in portal and jugular rat veins following $\mathbf{3 0} \mathbf{~ m g} / \mathbf{k g}$ oral administration of compounds 5, 7 and 8 in Sprague Dawley rats.

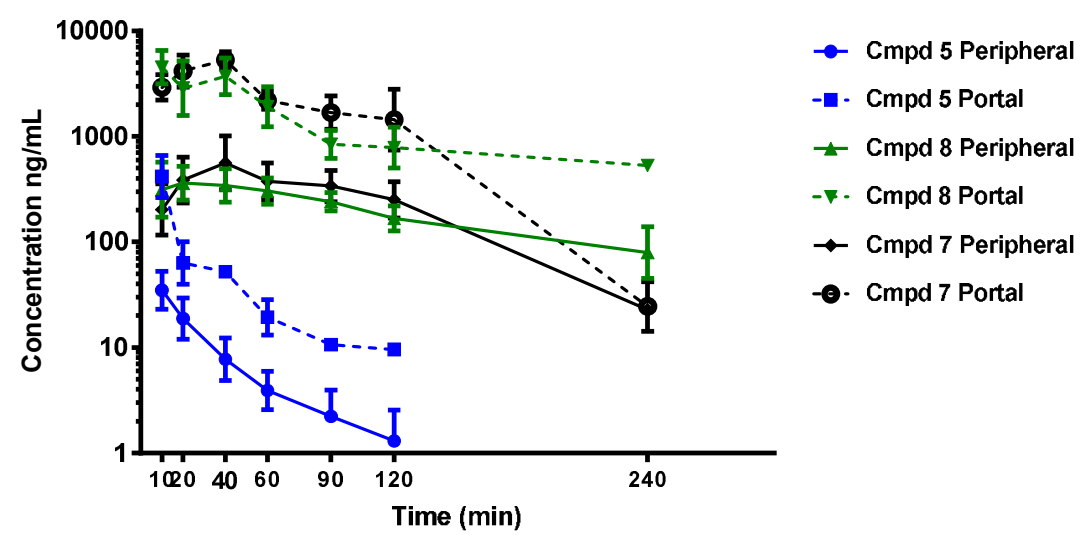

Figure 4S. Exposure of the niacin linker metabolites in portal and jugular rat veins following $30 \mathrm{mg} / \mathrm{kg}$ oral administration of compounds 5, 7 and 8 in Sprague Dawley rats.

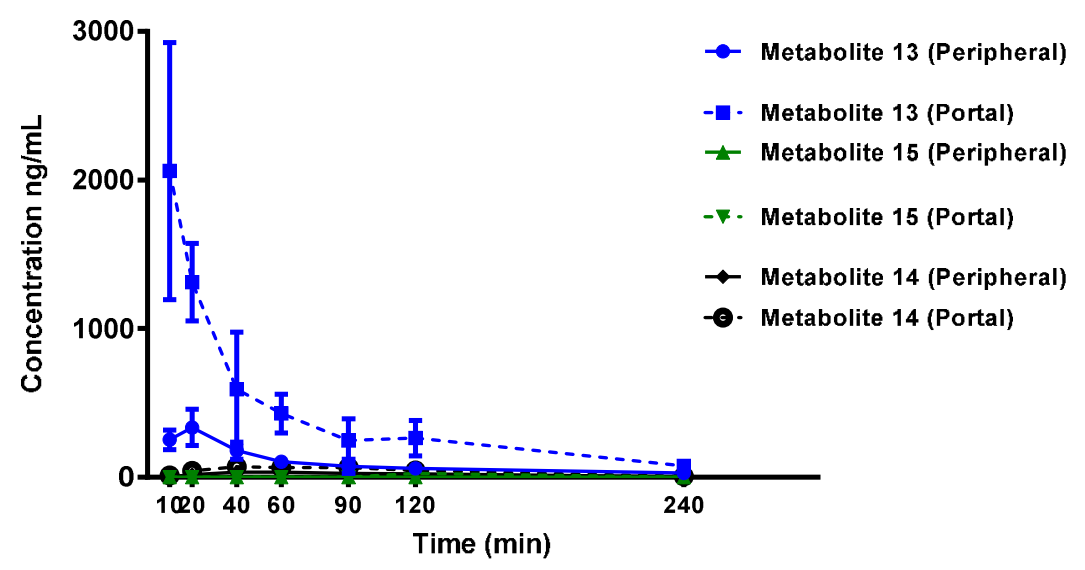


Figure 5S. Exposure of the nicotinuric acid metabolite in portal and jugular rat veins following $30 \mathrm{mg} / \mathrm{kg}$ oral administration of compounds 5, 7 and 8 in Sprague Dawley rats.

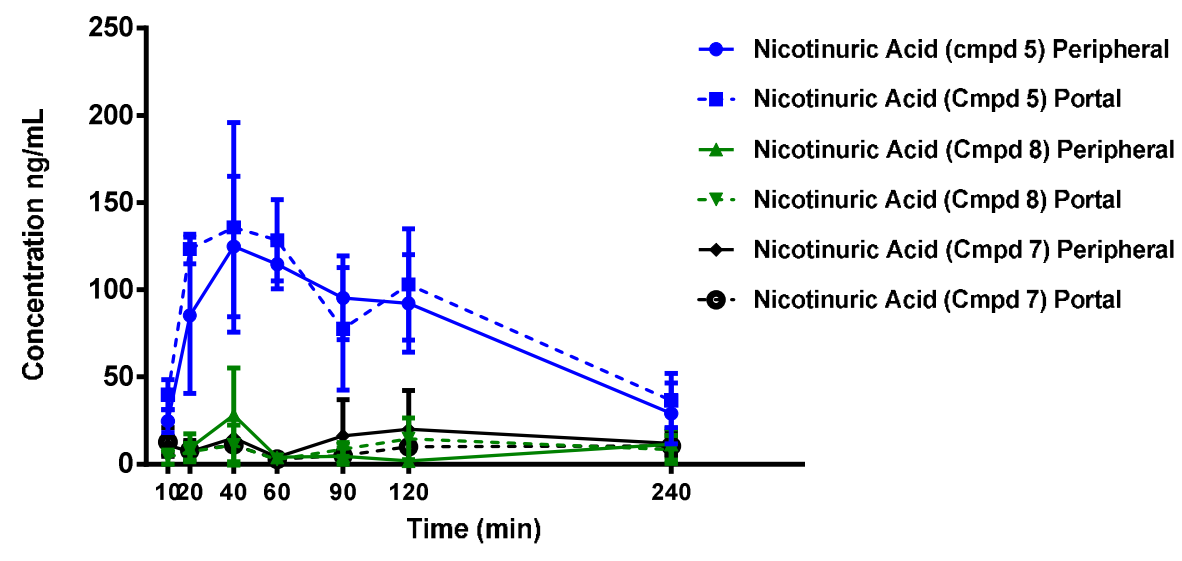


Tissue distribution study for compound 8: Tissue distribution and washout of compound 8 was also assessed in rats following once daily oral administration of $100 \mathrm{mg} / \mathrm{kg}$ for $3,7,10,14$, and 22 days and 14 days with 3 days washout (Day 17). Plasma, liver and intestine tissues were collected at 4 hours post dose. Compound $\mathbf{8}$ was cleared from tissue and plasma following the 3 days of washout (Figure 6S).

Figure 6S: Compound 8 tissue distribution with 3 day washout
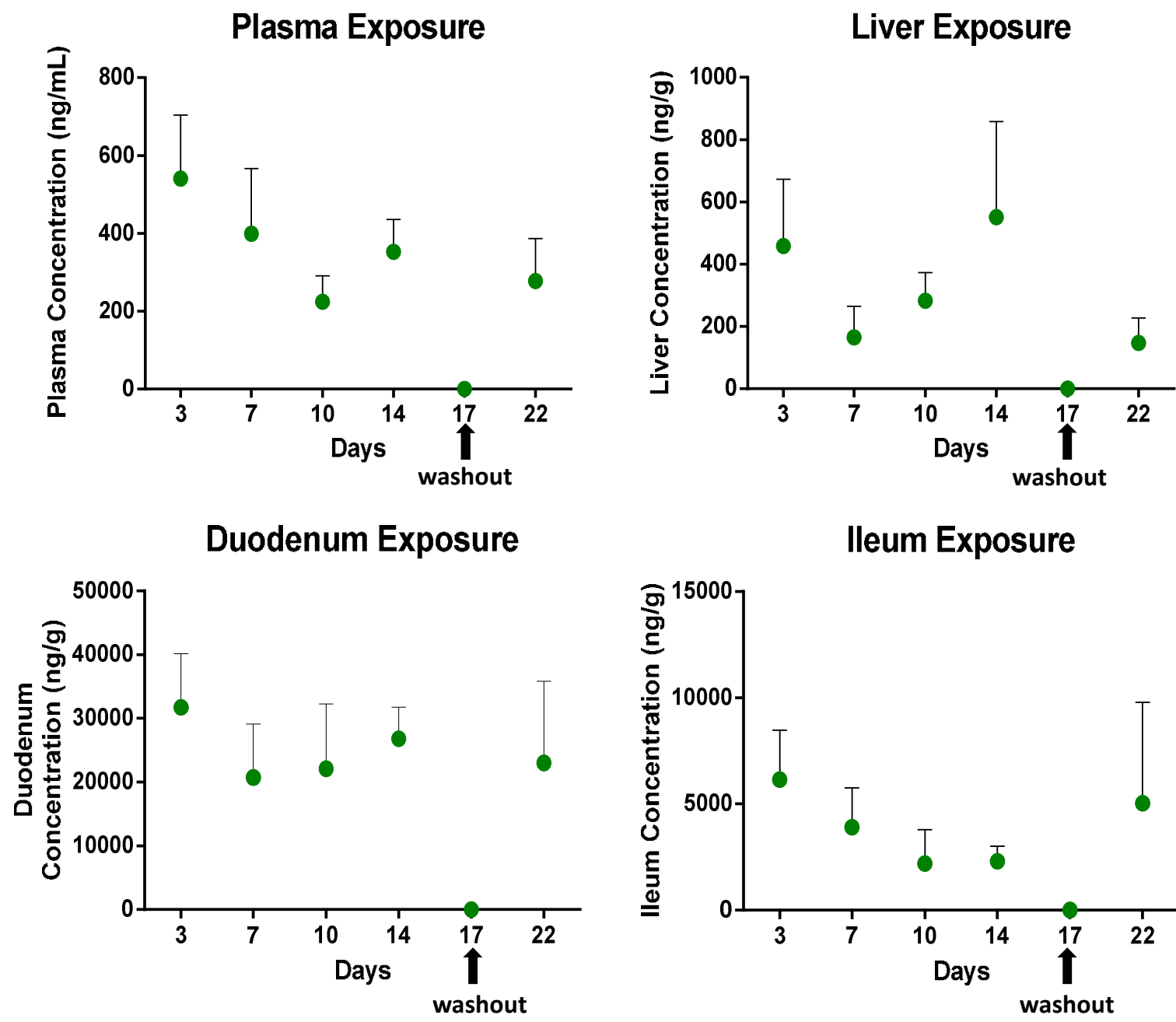

Ileum Exposure

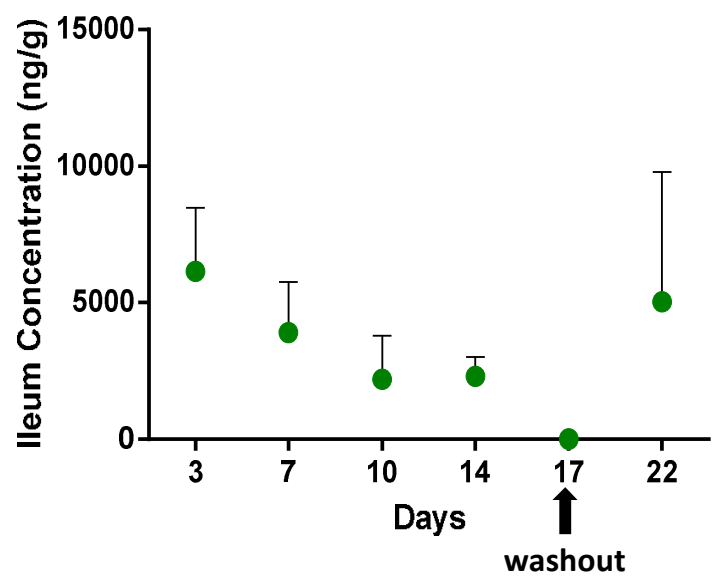


Preparation of 2-((5Z,8Z,11Z,14Z,17Z)-icosa-5,8,11,14,17-pentaenoyloxy)ethyl nicotinate (1): In a typical run, $\mathrm{NaHCO}_{3}(1.67 \mathrm{~g}, 19.84 \mathrm{mmol})$ and tetrabutylammonium hydrogensulfate $(0.16 \mathrm{~g}, 0.49 \mathrm{mmol})$ was added to a suspension of EPA ( $>95 \%$ purity, $1.5 \mathrm{~g}, 4.96 \mathrm{mmol})$ in $\mathrm{CH}_{2} \mathrm{Cl}_{2}(30 \mathrm{~mL})$ and $\mathrm{H}_{2} \mathrm{O}(30 \mathrm{~mL})$. The resulting reaction mixture was stirred at $\mathrm{rt}$ for $1 \mathrm{~h}$. A solution containing chloromethyl sulfochloridate $(0.95 \mathrm{~g}, 5.71 \mathrm{mmol})$ in $\mathrm{CH}_{2} \mathrm{Cl}_{2}(10 \mathrm{~mL})$ was added slowly in order to ensure that the temperature of the reaction did not rise above $30{ }^{\circ} \mathrm{C}$. Once the addition was completed, the resulting reaction mixture was stirred at $\mathrm{rt}$ for an additional $30 \mathrm{~min}$. The organic layer was separated, washed with brine $(3 \times 100 \mathrm{~mL})$, dried $\left(\mathrm{Na}_{2} \mathrm{SO}_{4}\right)$ and concentrated under reduced pressure. The resulting residue was purified with silica gel column chromatography (Pentanes/EtOAc $=20: 1)$ to afford $1.28 \mathrm{~g}$ of $(5 \mathrm{Z}, 8 \mathrm{Z}, 11 \mathrm{Z}, 14 \mathrm{Z}, 17 \mathrm{Z})$ chloromethyl icosa-5,8,11,14,17-pentaenoate (75\%) as yellow oil. To a solution of (5Z,8Z,11Z,14Z,17Z)-chloromethyl icosa-5,8,11,14,17-pentaenoate (1.28 g, $3.65 \mathrm{mmol})$ in $5 \mathrm{~mL}$ of DMF was added a solution of niacin $(0.53 \mathrm{~g}, 4.38 \mathrm{mmol}, 1.2 \mathrm{eq})$ and $\mathrm{Et}_{3} \mathrm{~N}(0.60 \mathrm{~mL}, 4.38$ $\mathrm{mmol}$ ) in $5 \mathrm{~mL}$ of DMF at $0{ }^{\circ} \mathrm{C}$. The resulting reaction mixture was stirred at $\mathrm{rt}$ for $16 \mathrm{~h}$ and then extracted with EtOAc $(3 \times 100 \mathrm{~mL})$. The organic layer was separated, washed with brine $(3 \times$ $100 \mathrm{~mL})$, dried $\left(\mathrm{Na}_{2} \mathrm{SO}_{4}\right)$ and concentrated under reduced pressure. The resulting residue was purified with silica gel column chromatography (Pentanes/EtOAc $=10: 1$ ) to afford $0.75 \mathrm{~g}$ of 2$((5 Z, 8 Z, 11 Z, 14 Z, 17 Z)$-icosa-5,8,11,14,17-pentaenoyloxy)ethyl nicotinate $(33 \%,>95 \%$ purity by LC/MS) as yellow oil. ${ }^{1} \mathrm{H}$ NMR $\left(400 \mathrm{MHz}, \mathrm{CDCl}_{3}\right) \delta 0.89(\mathrm{t}, J=7.6 \mathrm{~Hz}, 3 \mathrm{H}), 1.65-1.68(\mathrm{~m}, 2 \mathrm{H})$, 1.98-2.06 (m, 4H), 2.32-2.35 (m, 2H), 2.69-2.78 (m, 8H), 5.23-5.33 (m, 10H), $5.95(\mathrm{~s}, 2 \mathrm{H}), 7.32-$ 7.35(m, $1 \mathrm{H}), 8.24-8.26(\mathrm{~m}, 1 \mathrm{H}), 8.73-8.75(\mathrm{~m}, 1 \mathrm{H}), 9.18(\mathrm{~s}, 1 \mathrm{H}) .{ }^{1} \mathrm{H}$ NMR $\left(400 \mathrm{MHz}, \mathrm{CDCl}_{3}\right) \delta$ $9.25(\mathrm{dd}, J=2.2,0.9 \mathrm{~Hz}, 1 \mathrm{H}), 8.81(\mathrm{dd}, J=4.8,1.8 \mathrm{~Hz}, 1 \mathrm{H}), 8.32(\mathrm{dt}, J=8.0,2.0 \mathrm{~Hz}, 1 \mathrm{H}), 7.41$ (ddd, $J=8.0,4.8,1.0 \mathrm{~Hz}, 1 \mathrm{H}), 6.02(\mathrm{~s}, 2 \mathrm{H}), 5.56-5.17(\mathrm{~m}, 10 \mathrm{H}), 2.92-2.71(\mathrm{~m}, 8 \mathrm{H}), 2.41(\mathrm{t}, J$ $=7.5 \mathrm{~Hz}, 2 \mathrm{H}), 2.19-2.00(\mathrm{~m}, 4 \mathrm{H}), 1.74(\mathrm{p}, J=7.5 \mathrm{~Hz}, 2 \mathrm{H}), 0.97(\mathrm{t}, J=7.5 \mathrm{~Hz}, 3 \mathrm{H}) . \mathrm{MS}(\mathrm{ESI})$ Calcd for $\mathrm{C}_{27} \mathrm{H}_{35} \mathrm{NO}_{4} \mathrm{~m} / z$ 437, found $438(\mathrm{M}+\mathrm{H})^{+}$.

\section{Preparation of 2-((5Z,8Z,11Z,14Z,17Z)-icosa-5,8,11,14,17-pentaenoyloxy)ethyl nicotinate} (2): In a typical run, $\mathrm{Et}_{3} \mathrm{~N}(34.6 \mathrm{~mL}, 248 \mathrm{mmol})$ and 2-chloroethanol $(4.16 \mathrm{~mL}, 62 \mathrm{mmol})$ were added to a solution containing DMAP $(36.7 \mathrm{mg}, 3.1 \mathrm{mmol})$ in $\mathrm{CH}_{2} \mathrm{Cl}_{2}(124 \mathrm{~mL})$. The resulting reaction mixture was cooled to $0{ }^{\circ} \mathrm{C}$ and nicotinyl chloride hydrochloride $(16.6 \mathrm{~g}, 93 \mathrm{mmol})$ was added in portions as a slurry in $\mathrm{CH}_{2} \mathrm{Cl}_{2}(100 \mathrm{~mL})$. The resulting reaction mixture was stirred at 0 ${ }^{\circ} \mathrm{C}$ for $3 \mathrm{~h}$ and then quenched with saturated aq $\mathrm{NH}_{4} \mathrm{Cl}$. The aqueous layer was further extracted with $\mathrm{CH}_{2} \mathrm{Cl}_{2}$. The combined organic layers were washed with water, brine, dried $\left(\mathrm{Na}_{2} \mathrm{SO}_{4}\right)$ and concentrated under reduced pressure to afford $10.5 \mathrm{~g} 2$-chloroethyl nicotinate $\mathbf{1 0}(61 \%)$. To 2chloroethyl nicotinate $10(370 \mathrm{mg}, 2 \mathrm{mmol})$ in DMF $(2 \mathrm{~mL})$ was added EPA ( $>95 \%$ purity, 605 $\mathrm{mg}, 2 \mathrm{mmol})$, followed by DBU $(152 \mathrm{mg}, 1 \mathrm{mmol})$. The resulting reaction mixture was warmed to $70{ }^{\circ} \mathrm{C}$ and stirred for $16 \mathrm{~h}$. It was then cooled to rt and diluted with $\mathrm{CH}_{2} \mathrm{Cl}_{2}$. The organic layer was washed with saturated aq $\mathrm{NH}_{4} \mathrm{Cl}$, brine, dried $\left(\mathrm{Na}_{2} \mathrm{SO}_{4}\right)$ and concentrated under reduced pressure. The resulting residue was purified by silica gel chromatography (gradient elution:0$40 \%$ EtOAc in pentane) to afford $325 \mathrm{mg}$ of 2-((5Z,8Z,11Z,14Z,17Z)-icosa-5,8,11,14,17pentaenoyloxy)ethyl nicotinate as a yellow oil $\left(36 \%,>95 \%\right.$ purity by LC/MS). ${ }^{1} \mathrm{H}$ NMR (400 $\left.\mathrm{MHz}, \mathrm{CDCl}_{3}\right) \delta 9.23(\mathrm{~d}, J=1.7 \mathrm{~Hz}, 1 \mathrm{H}), 8.79(\mathrm{dd}, J=4.8,1.5 \mathrm{~Hz}, 1 \mathrm{H}), 8.30(\mathrm{dt}, J=7.9,1.9 \mathrm{~Hz}$, $1 \mathrm{H}), 7.40$ (dd, $J=7.9,4.9 \mathrm{~Hz}, 1 \mathrm{H}), 5.37$ (ddd, $J=10.4,9.1,4.1 \mathrm{~Hz}, 10 \mathrm{H}), 4.59-4.53(\mathrm{~m}, 2 \mathrm{H})$, $4.47-4.39$ (m, 2H), $2.88-2.74$ (m, 8H), 2.36 (t, $J=7.6 \mathrm{~Hz}, 2 \mathrm{H}), 2.17-1.98$ (m, 4H), 1.71 (p, $J$ 
$=7.5 \mathrm{~Hz}, 2 \mathrm{H}), 0.97(\mathrm{t}, J=7.5 \mathrm{~Hz}, 3 \mathrm{H})$. MS (ESI) Calcd for $\mathrm{C}_{28} \mathrm{H}_{37} \mathrm{NO}_{4} \mathrm{~m} / z$ 451, found $452(\mathrm{M}+$ $\mathrm{H})^{+}$.

\section{Preparation of 2-((5Z,8Z,11Z,14Z,17Z)-icosa-5,8,11,14,17-pentaenamido)ethyl nicotinate}

(3): In a typical run, ethanolamine (1 g, $16.4 \mathrm{mmol})$ was taken up in $20 \mathrm{~mL} \mathrm{CH}_{2} \mathrm{Cl}_{2}$, followed by the addition of EPA ( $>95 \%$ purity, $4.7 \mathrm{~g}, 15.58 \mathrm{mmol}) \mathrm{EDC}(3.45 \mathrm{~g}, 18.0 \mathrm{mmol})$, HOBT ( $3.05 \mathrm{~g}$, $18.0 \mathrm{mmol})$ and $\mathrm{Et}_{3} \mathrm{~N}(3 \mathrm{~mL}, 21.3 \mathrm{mmol})$. The resulting reaction mixture was stirred at $\mathrm{rt}$ for $16 \mathrm{~h}$ and then concentrated under reduced pressure. The resulting residue was purified by silica gel chromatography (gradient elution: 0-60\% EtOAc in pentane) to afford $4.32 \mathrm{~g}$ of (5Z,8Z,11Z,14Z,17Z)-N-(2-hydroxyethyl)icosa-5,8,11,14,17-pentaenamide. This material (4.32 g, $12.5 \mathrm{mmol})$ was taken up in $20 \mathrm{~mL}$ anhydrous $\mathrm{CH}_{2} \mathrm{Cl}_{2}$ along with nicotinoyl chloride $(1.75 \mathrm{~g}$, $12.5 \mathrm{mmol})$ and $\mathrm{Et}_{3} \mathrm{~N}(5.2 \mathrm{~mL}, 37.5 \mathrm{mmol})$. The resulting reaction mixture was stirred at $\mathrm{rt}$ for $16 \mathrm{~h}$ and then washed with half-saturated $\mathrm{NH}_{4} \mathrm{Cl}$, brine, dried $\left(\mathrm{Na}_{2} \mathrm{SO}_{4}\right)$ and concentrated under reduced pressure. The resulting residue was purified by silica gel chromatography (gradient elution: $0-6 \% \mathrm{MeOH}$ in $\left.\mathrm{CH}_{2} \mathrm{Cl}_{2}\right)$ to afford $4.66 \mathrm{~g}$ of 2-((5Z,8Z,11Z,14Z,17Z)-icosa-5,8,11,14,17pentaenamido)ethyl nicotinate $\left(63 \%,>95 \%\right.$ purity by LC/MS). ${ }^{1} \mathrm{H}$ NMR $\left(400 \mathrm{MHz}, \mathrm{CDCl}_{3}\right) \delta$ $9.22(\mathrm{~d}, J=2.1 \mathrm{~Hz}, 1 \mathrm{H}), 8.80(\mathrm{dd}, J=4.9,1.7 \mathrm{~Hz}, 1 \mathrm{H}), 8.30(\mathrm{dt}, J=8.0,2.0 \mathrm{~Hz}, 1 \mathrm{H}), 7.41(\mathrm{dd}, J$ $=7.9,4.8 \mathrm{~Hz}, 1 \mathrm{H}), 5.78(\mathrm{~d}, J=6.2 \mathrm{~Hz}, 1 \mathrm{H}), 5.35(\mathrm{~m}, 9 \mathrm{H}), 4.46(\mathrm{t}, J=5.3 \mathrm{~Hz}, 2 \mathrm{H}), 3.68(\mathrm{q}, J=$ $5.5 \mathrm{~Hz}, 2 \mathrm{H}), 2.81(\mathrm{dq}, J=13.9,6.3,5.6 \mathrm{~Hz}, 8 \mathrm{H}), 2.20(\mathrm{dd}, J=8.4,6.9 \mathrm{~Hz}, 2 \mathrm{H}), 2.16-2.01(\mathrm{~m}$, $4 \mathrm{H}), 1.72$ (p, $J=7.4 \mathrm{~Hz}, 2 \mathrm{H}$ ), 0.97 (t, $J=7.5 \mathrm{~Hz}, 3 \mathrm{H}$ ). MS (ESI) Calcd for $\mathrm{C}_{26} \mathrm{H}_{40} \mathrm{~N}_{2} \mathrm{O}_{3} \mathrm{~m} / z$ 428, found $429(\mathrm{M}+\mathrm{H})^{+}$.

\section{Preparation of 2-((5Z,8Z,11Z,14Z,17Z)-icosa-5,8,11,14,17-pentaenamido)ethyl nicotinate}

(4): The procedure detailed above for the preparation of $\mathbf{3}$ was used with the following changes: niacin was used in place of EPA and (5Z,8Z,11Z,14Z,17Z)-icosa-5,8,11,14,17-pentaenoyl chloride was used in place of nicotinyl chloride. ${ }^{1} \mathrm{H}$ NMR $\left(400 \mathrm{MHz}, \mathrm{CDCl}_{3}\right) \delta 9.07(\mathrm{~d}, J=2.3$ $\mathrm{Hz}, 1 \mathrm{H}), 8.72(\mathrm{dd}, J=4.9,1.7 \mathrm{~Hz}, 1 \mathrm{H}), 8.12(\mathrm{dt}, J=7.9,2.0 \mathrm{~Hz}, 1 \mathrm{H}), 3.72-3.66(\mathrm{~m}, 0 \mathrm{H}), 7.70$ $-7.63(\mathrm{~m}, 1 \mathrm{H}), 3.79-3.72(\mathrm{~m}, 0 \mathrm{H}), 7.38(\mathrm{dd}, J=7.9,4.8 \mathrm{~Hz}, 1 \mathrm{H}), 6.15(\mathrm{~d}, J=6.2 \mathrm{~Hz}, 1 \mathrm{H}), 1.40$ $-1.34(\mathrm{~m}, 1 \mathrm{H}), 5.44-5.25(\mathrm{~m}, 4 \mathrm{H}), 3.65-3.50(\mathrm{~m}, 4 \mathrm{H}), 1.34-1.32(\mathrm{~m}, 1 \mathrm{H}), 2.76(\mathrm{t}, J=6.2$ $\mathrm{Hz}, 2 \mathrm{H}), 2.25-2.16(\mathrm{~m}, 2 \mathrm{H}), 2.03(\mathrm{dq}, J=9.7,6.7 \mathrm{~Hz}, 4 \mathrm{H}), 3.24-3.12(\mathrm{~m}, 1 \mathrm{H}), 0.88(\mathrm{t}, J=6.7$ $\mathrm{Hz}, 2 \mathrm{H}), 1.32-1.29(\mathrm{~m}, 3 \mathrm{H}), 1.53-1.41(\mathrm{~m}, 4 \mathrm{H}), 1.31-1.19(\mathrm{~m}, 11 \mathrm{H})$. MS (ESI) Calcd for $\mathrm{C}_{26} \mathrm{H}_{40} \mathrm{~N}_{2} \mathrm{O}_{3} m / z$ 428, found $429(\mathrm{M}+\mathrm{H})^{+}$. 

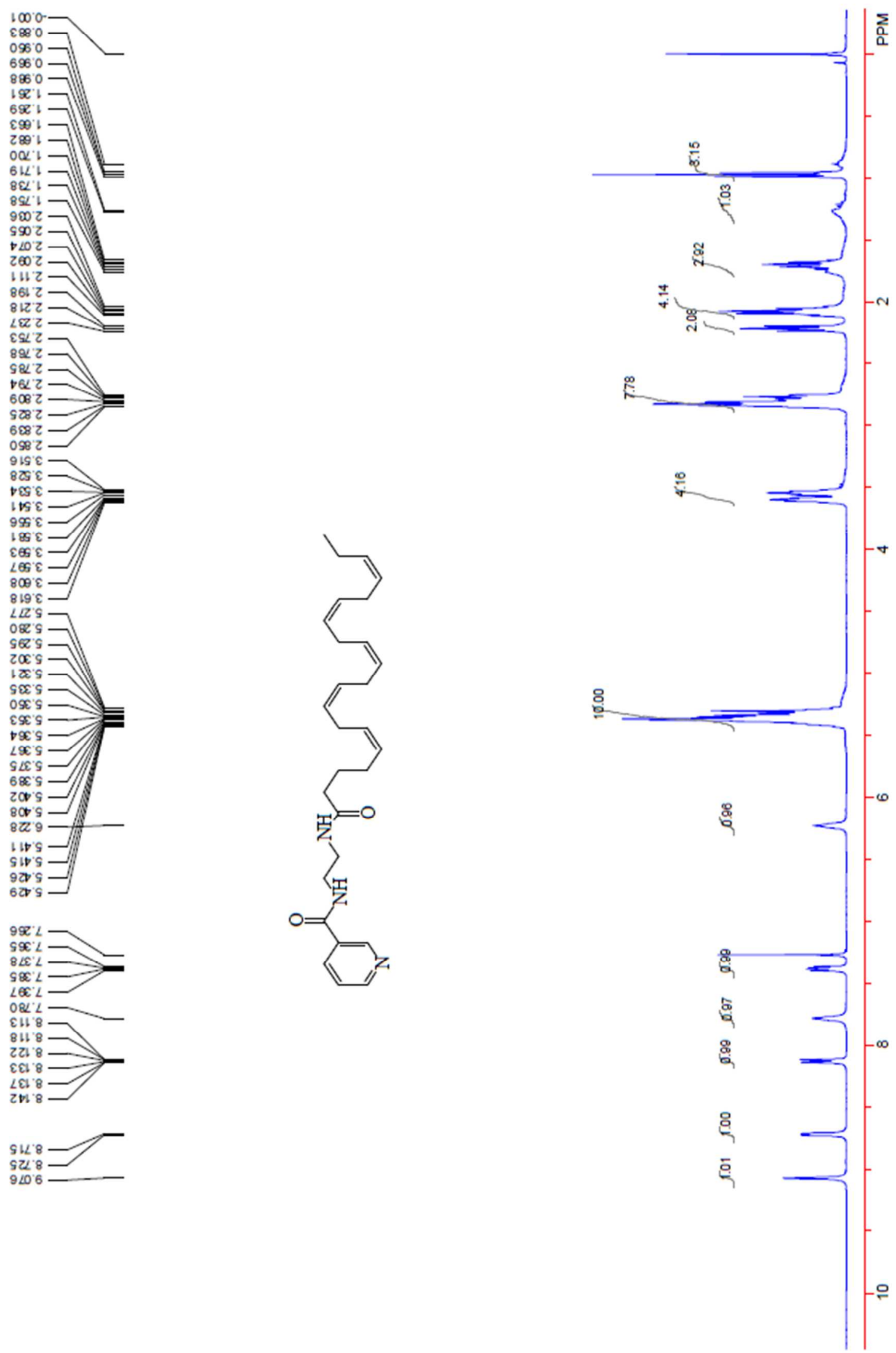


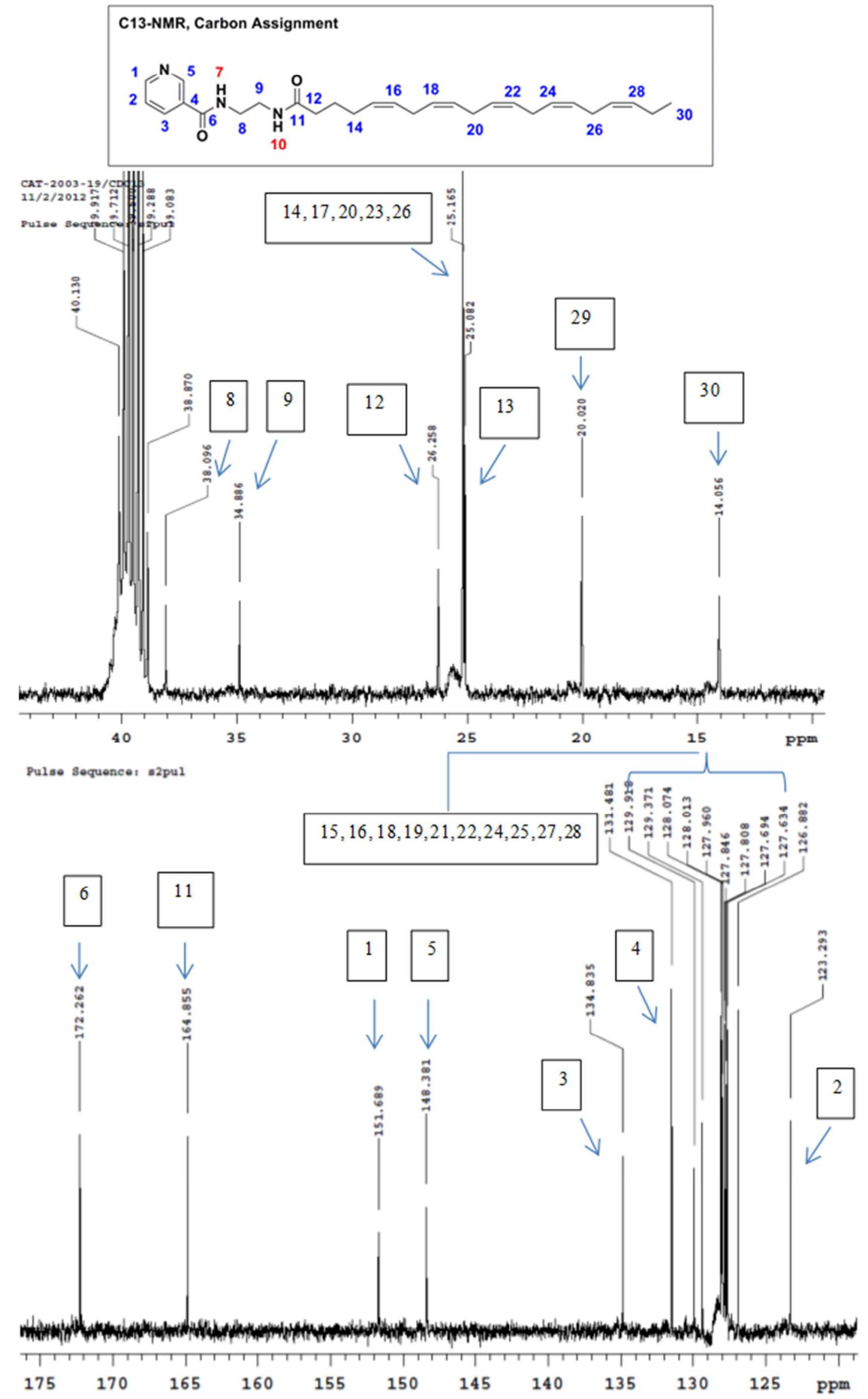



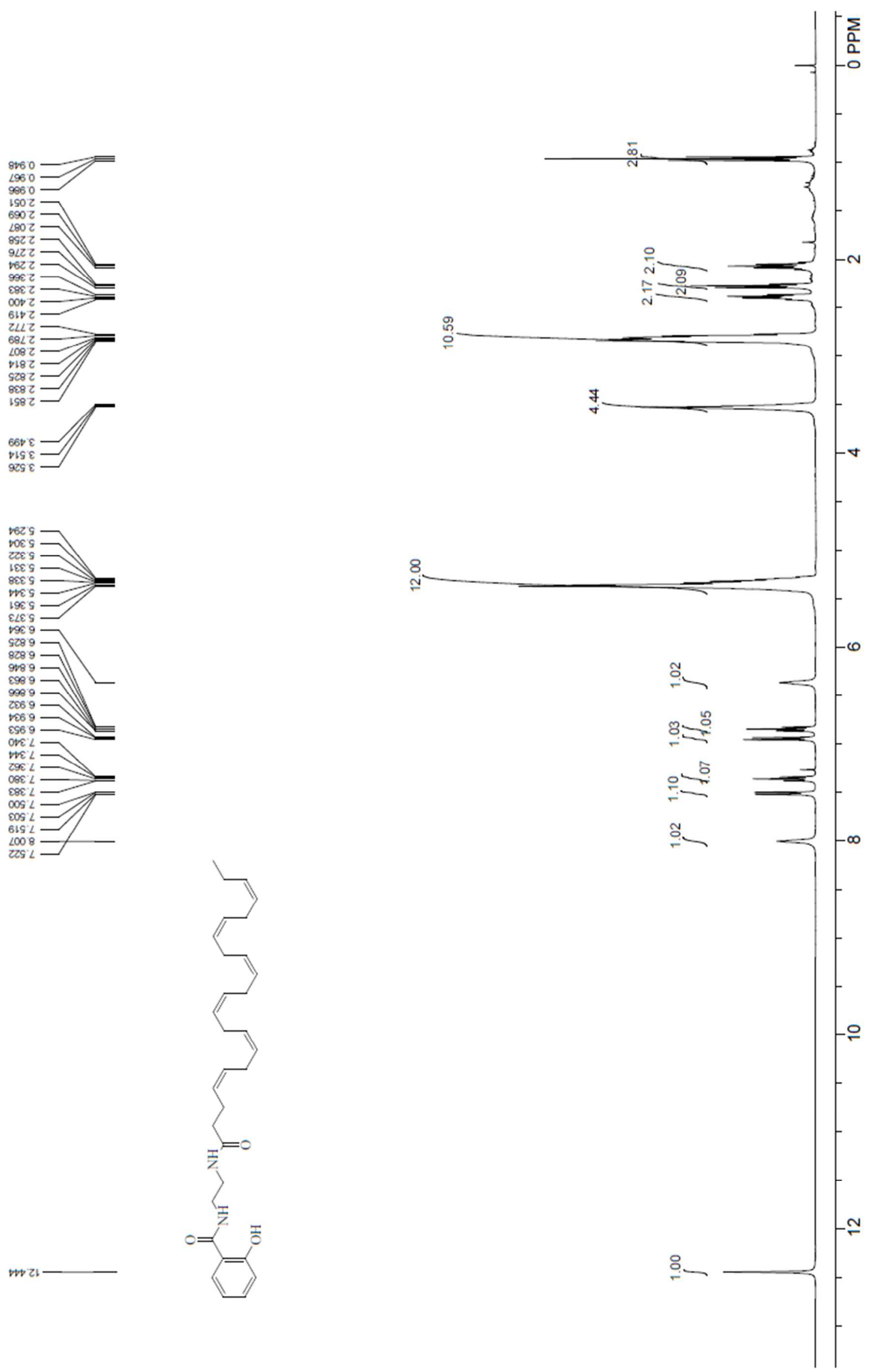

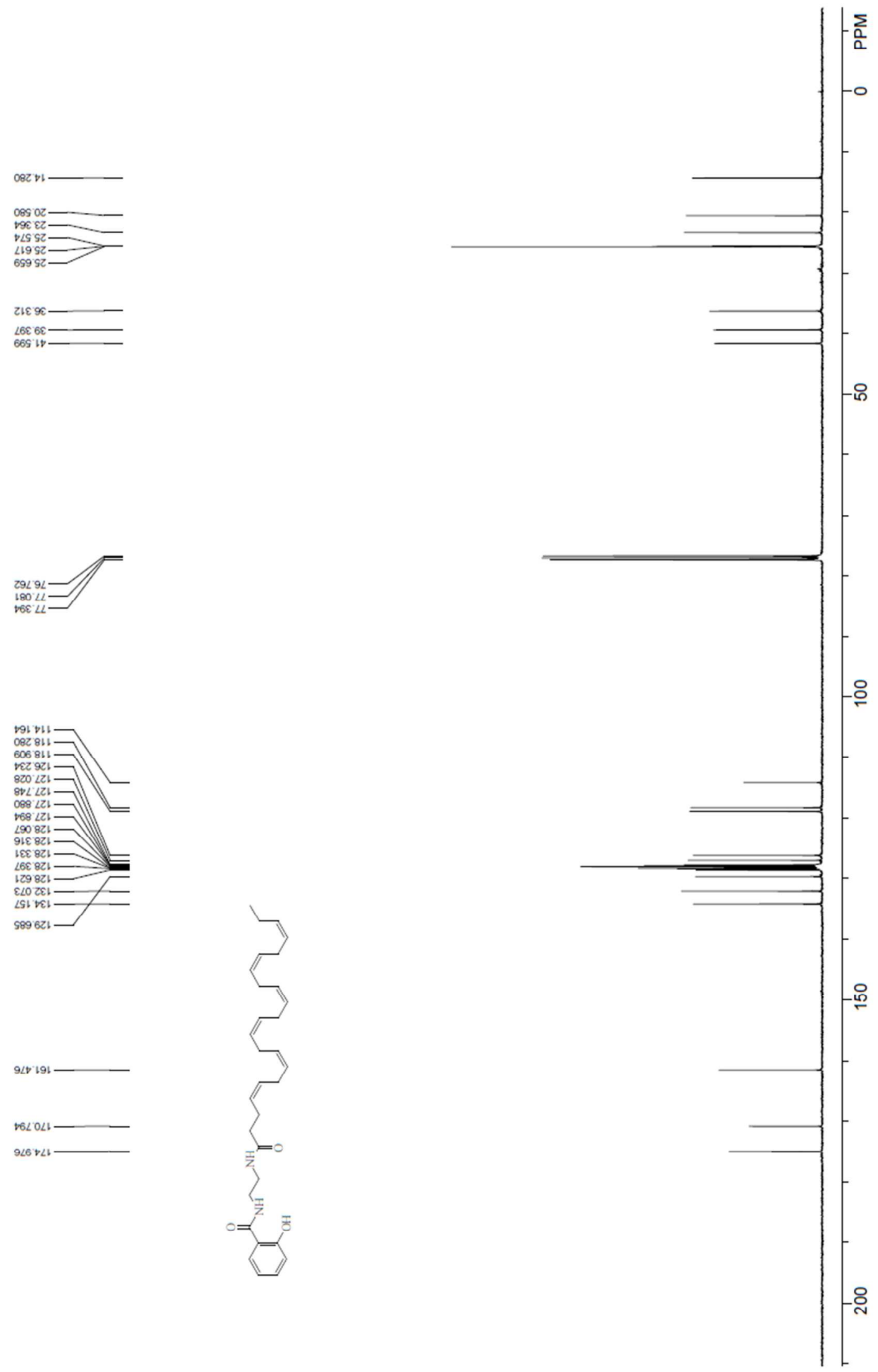